\title{
Resorpcja zewnętrzna korzeni drugiego zęba trzonowego szczęki spowodowana nieprawidłowym wyrzynaniem się zęba mądrości
}

\author{
External resorption of second molar roots caused by improper eruption \\ of a retained third molar in the maxilla
}

Katedra i Klinika Chirurgii Stomatologicznej, Uniwersytet Medyczny im. Karola Marcinkowskiego w Poznaniu

DOI: http://dx.doi.org/10.20883/df.2016.15

\section{Streszczenie}

Autorzy pracy opisali rzadkie powikłanie - resorpcję korzeni górnego drugiego zęba trzonowego spowodowaną nieprawidłowym wyrzynaniem się trzeciego zęba trzonowego szczęki. Przedstawiono aktualną wiedzę o zjawisku resorpcji, a także sposób postępowania diagnostycznego i operacyjnego w zaprezentowanym przypadku.

Słowa kluczowe: resorpcja zęba, ząb mądrości, trzeci trzonowiec, nieprawidłowe wyrzynanie zęba.

\begin{abstract}
The authors present a rare complication of the resorption of a second maxillary molar, the root of which resorbed due to the improper eruption of a retained third molar. Current knowledge about the phenomenon of resorption is presented as well as the diagnostic process and surgical treatment of the case.
\end{abstract}

Keywords: root resorption, wisdom teeth, eruption disorders.

\begin{abstract}
Wstęp
Resorpcja to proces zarówno fizjologiczny, jak i patologiczny, w którym dochodzi do utraty zmineralizowanych tkanek zęba, a w zaawansowanych przypadkach również kości wyrostka zębodołowego [1]. Resorpcja fizjologiczna nazywana inaczej rozwojowa obserwowana jest $w$ trakcie wymiany uzębienia mlecznego na stałe, inicjowana mniej więcej 3 lata przed fizjologiczną wymianą uzębienia. Rozpoczyna się ona niszczeniem przez osteoklasty przegrody kostnej, która oddziela zawiązek zęba stałego od korzenia zęba mlecznego. Proces ten stymulowany jest rozwojem zawiązka zęba stałego, a także przez gruczoły wydzielania wewnętrznego. Proces patologicznej resorpcji dotyczy głównie zębów stałych. Wyróżniamy resorpcję wewnętrzną zapalną i zamienną, w których utrata tkanek przebiega od strony kanału korzeniowego [2] i resorpcję zewnętrzną zapalną, powierzchniową i zamienną, w których proces niszczenia korzeni następuje od strony ozębnej i cementu korzeniowego, postępując w kierunku miazgi. Resorpcja zewnętrzna zapalna zaczynająca się od cementu może obejmować również zębinę, co prowadzi do skrócenia korzenia lub nawet jego całkowitego zniszczenia [3]. Resorpcja zewnętrzna może być spowodowana między innymi leczeniem ortodontycznym, uciskiem wywieranym przez zęby zatrzymane, torbiele i nowotwory, przewlekłym zapaleniem tkanek okołowierzchołkowych w następstwie urazów zębów,
\end{abstract}

a nawet zaburzeniami $w$ miejscowym krążeniu krwi, niedoborem witaminy $A$, zaburzeniami hormonalnymi oraz czynnikami genetycznymi [4]. Patomechanizm rozwoju resorpcji zewnętrznej w zależności od czynnika sprawczego został opisany przez Fussa i wsp. w 2003 roku [5]. Autor podzielił resorpcje zębów na resorpcje związane z infekcja miazgi, zapaleniem przyzębia, uciskiem wywieranym przez leczenie ortodontyczne, zęby zatrzymane i nowotwory oraz resorpcje ankylotyczne. Za przyczynę resorpcji uważa się utratę ochronnej warstwy cementoblastów i pozostałości nabłonkowych Malasseza, co powoduje ułatwiony dostęp makrofagów i osteoblastów usuwających zniszczone włókna ozębnej i cement na powierzchni korzenia [6]. Urazy oraz inne bodźce drażniące pobudzają bowiem czynniki inicjujące aktywność osteoklastów: czynnik aktywujący osteoklasty, czynnik chemotaktyczny makrofagów, prostaglandyny, heparynę i produkty bakteryjne [7]. W resorpcji powierzchniowej miejsce uszkodzenia resorbowane jest przez makrofagi i osteoklasty powstają płytkie zatoki resorpcyjne. Resorpcja zapalna (infekcyjna) może mieć przebieg gwałtowny i w ciągu kilku miesięcy może doprowadzić do zniszczenia całego korzenia zęba. Bakterie i toksyny bakteryjne $z$ kanalików zębinowych wywołują zapalenie ozębnej i resorpcję przyległej kości. Stan ten przyspiesza rozpuszczanie powierzchni korzenia [3]. Resorpcja zamienna (wymienna, ankylotyczna) polega na odkładaniu w miejscach 


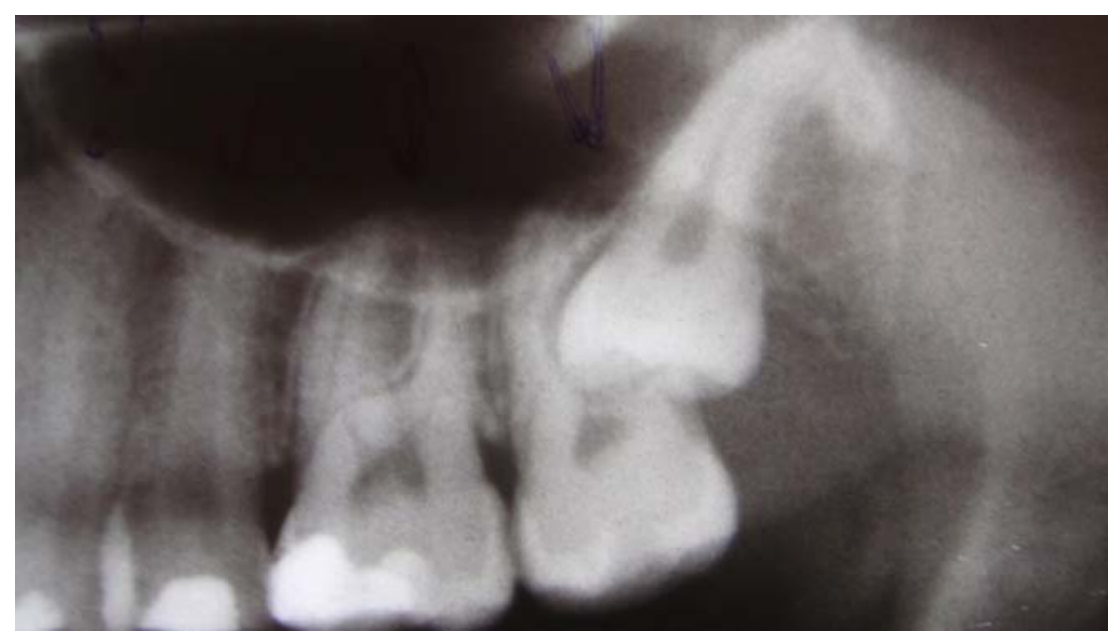

Rycina 1. Na zdjęciu OPG ząb 28 rzutujący się na korzeń zęba 27

Figure 1. The tooth 28 next to a root of the tooth 27 visualised on the OPG $x$-ray

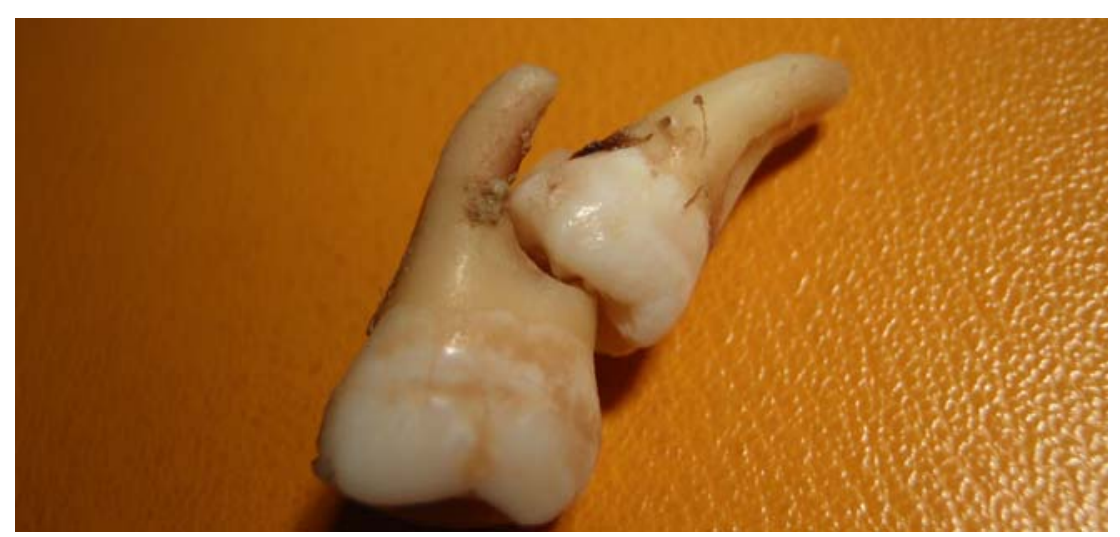

Rycina 2. Odtworzenie ułożenia zębów 27 i 28

Figure 2. Reconstruction of position of teeth 27 and 28

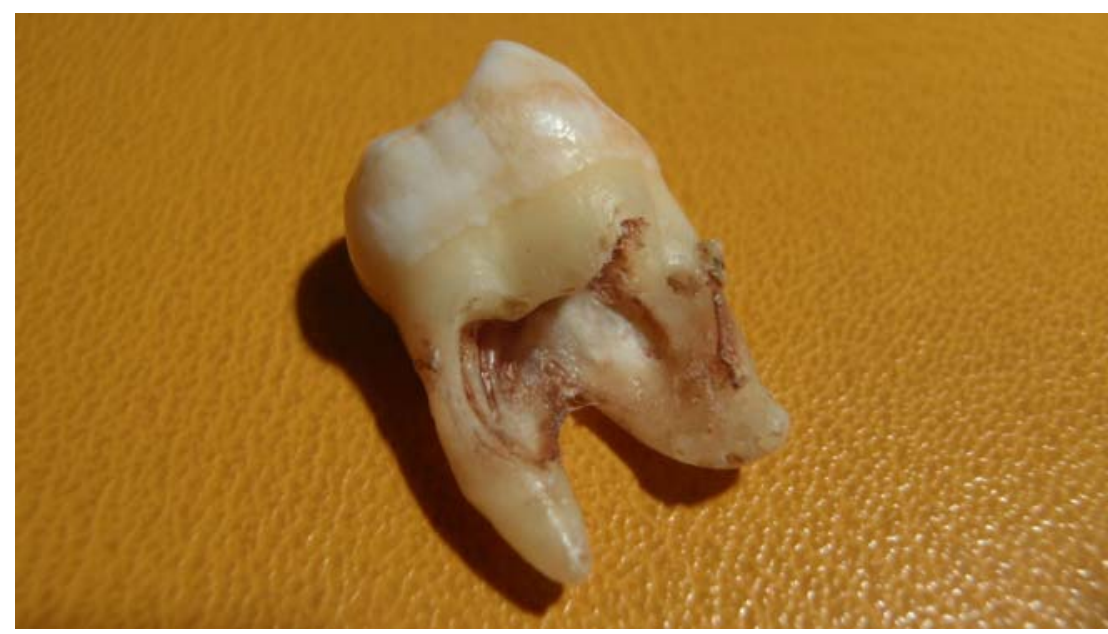

Rycina 3. Resorpcja dystalnej powierzchni korzeni zęba 27

Figure 3. Resorption of a distal surface of a tooth 27

zatok resorpcyjnych nowej tkanki kostnej przy udziale komórek szpiku kostnego oraz gojenia od strony ozębnej przez wytwarzanie cementu i włókien Sharpeya. Najczęściej zębami zatrzymanymi, które indukują resorpcję zębów stałych, są kły szczęki i trzecie trzonowce żuchwy. Klinicyści wciąż nie w pełni uwzględniają ich zdolności do powodowania procesów resorpcyjnych uważając, że zatrzymane zęby mądrości można pozostawić w kości, jeżeli bezobjawowo tkwią w tkankach. 
A według Siegel i wsp. trudno ten proces przewidzieć, rozpoznać i leczyć [8].

Dla zilustrowania naszych obserwacji przedstawiamy rzadki przypadek - resorpcji zewnętrznej korzeni drugiego zęba trzonowego szczęki wywołany wyrzynaniem się zęba „mądrości“.

\section{Opis przypadku}

Pacjentka (lat 36) zgłosiła się do gabinetu chirurgicznego z powtarzającymi się dolegliwościami z powodu wyrzynającego się zęba 28 . Z wywiadu wynikało, że dwukrotnie z powodu silnego bólu w okolicy lewego guza szczęki przyjmowała antybiotyk. W chwili zgłoszenia pacjentka nie skarżyła się na żadne dolegliwości. W badaniu przedmiotowym w okolicy lewego guza szczęki nie stwierdzono wykładników procesu zapalnego, jak również obecności zęba 28. Na zdjęciu ortopantomograficznym widoczny był ząb 28 rzutujący się na korzeń zęba 27 (Rycina 1). Z powodu nawracających procesów zapalnych zadecydowano o konieczności usunięcia zatrzymanego zęba 28. W trakcie zabiegu, po nacięciu i odpreparowaniu płata śluzówkowo-okostnowego, odsłonięto kość wyrostka zębodołowego z widoczną koroną zęba 28 leżącą w okolicy trifurkacji zęba 27 . Z powodu widocznej resorpcji korzenia policzkowego dalszego zęba 27 zadecydowano o jego usunięciu. Ocena wzrokowa umożliwiła stwierdzenie resorpcji usuniętego zęba 27 obejmującej nie tylko korzeń dystalny policzkowy, ale również połowę korzenia policzkowgo bliższego i podniebiennego. W dalszej kolejności usunięto również ząb 28 (Rycina 2 i 3). Po ekstrakcji ranę zaopatrzono szwami nieresorbowalnymi.

\section{Omówienie}

Resorpcje drugich zębów trzonowych wywołane wyrzynaniem się zębów „mądrości” należą do rzadkości. Procesy te przebiegają często bez wyraźnych objawów klinicznych i zęby nadal mogą wykazywać reakcję na bodźce termiczne i elektryczne. Zaawansowany proces resorpcyjny i wywołane nim dolegliwości bólowe skłaniają pacjenta do wizyty w gabinecie stomatologicznym. Tak zaawansowany stan tkanek sprawia, że rokowanie dotyczące zachowanie zęba jest niepewne. Rutynowe zdjęcie rentgenowskie w przypadku nakładania się zębów również nie zawsze pozwala na wczesne postawienie diagnozy o resorpcji zewnętrznej. Radiologiczne cechy resorpcji zewnętrznej opisane przez Makkesa i Thodena van Velzena $w$ tych przypadkach nie są możliwe do scharakteryzowania [9]. Często przyczyną jest nakładanie się zęba „mądrości” na drugi ząb trzonowy. Precyzyjnych informacji dostarcza nam w tych przypadkach badanie za pomocą tomografii komputerowej. To obrazowanie umożliwia ponadto ocenę stopnia i rozległość resorpcji korzeni zębów trzonowych, jednak rutynowo nie jest stosowane w diagnostyce dentystycznej. Dolegliwości bólowe świadczą o zaawansowaniu proce- su, który obejmuje okolicę miazgi zęba i świadczy o znacznym zaawansowaniu resorpcji korzenia. Guz szczęki jest zbudowany głównie z kości gąbczastej i bardzo często z powodu braku miejsca w łuku i miękkiej kości górne zęby mądrości wyrzynają się dopoliczkowo. Występowanie resorpcji zębów trzonowych szczęki z powodu wyrzynania się górnych zębów „mądrości” należy do wyjątków. W opisanym przypadku ząb 28 okazał się ponadto szczątkowym zębem o nietypowym kształcie, który przyczynił się do uszkodzenia ciągłości tkanek prawidłowego zęba trzonowego.

\section{Oświadczenia}

Oświadczenie dotyczące konfliktu interesów

Autorzy deklarują brak konfliktu interesów w autorstwie oraz publikacji pracy.

\section{Źródła finansowania}

Autorzy deklarują brak źródeł finansowania.

\section{Piśmiennictwo}

[1] Jasiński P, Sobiech P, Korporowicz E, Resorpcja zewnętrzna korzenia spowodowana urazem - opis przypadku. Nowa Stomat. 2011:4:158-162.

[2] Ciesielski P, Łaszkiewicz J. Wewnętrzna resorpcja zapalna - na podstawie piśmiennictwa i własnych obserwacji. Czas Stomatol. 2008;61(1):40-47.

[3] Jańczuk Z, Arłukowicz E, Dembowska E, Suszczewicz A. Próba leczenia prawie całkowitej resorpcji pourazowej korzeni górnych siekaczy przyśrodkowych. Mag Stom. 2005;9:82-86.

[4] Jurczak A, Kołdziej I, Kościelniak D, Słowik J. Resorpcja zewnętrzna zamienna korzenia zęba jako późne powikłanie pourazowe u pacjentów w wieku rozwojowym. Implantoprot. 2009;4(37):41-43.

[5] Fuss Z, Tsesis I, Lin S. Root resorption- diagnosis, classification and treatment choices based on stimulation factors. Dental Traumat. 2003;19(4):175-182.

[6] Andreasen JO i wsp. Pourazowe uszkodzenia zębów. Urban\&Partner 2005; 47-83.

[7] Al-Momani Z, Nixon P. Resorpcja wewnętrzna i zewnętrzna korzenia zęba - etiologia, rozpoznawanie i możliwości leczenia. Med Prakt Stom. 2013;4:51-58.

[8] Siegel R, Stós W, Dyras M, Urbanik A, Wojciechowski W, Sztuk S. Ocena stopnia i rozległości resorpcji korzeni zębów siecznych sąsiadujących z zatrzymanymi kłami górnymi. Przegląd Lekarski. 2010;67(4):268-274.

[9] Makkes PC, Thoden van Velzen SR. Cervical external root resorption. J Dent. 1975;3(5):217-222.

Zaakceptowano do edycji: 2016-04-28 Zaakceptowano do publikacji: 2016-05-06
Adres do korespondencji:
Krzysztof Sidorowicz
Katedra i Klinika Chirurgii Stomatologicznej
Uniwersytet Medyczny im. Karola Marcinkowskiego
w Poznaniu
ul. Bukowska 70, 60-139 Poznań
tel.: +48 603589667
e-mail: ksido@wp.pl 